\title{
Antibiotic Resistance Mechanisms of Impetigo Contagiosa Bacteria (Staphylococcus aureus and Streptococcus pyogenes) in Infants and the Efficacy of Bridelia ferruginea Benth. (Phyllanthaceae) and Terminalia avicennioides Guill. \& Perr. (Combretaceae) Ethanol Extracts
}

\author{
* ${ }^{1 b}$ Cletus Anes UKWUBILE, ${ }^{2 .}$ Otalu OTALU Jr., \\ ${ }^{\mathrm{b}}$ Tajudeen Babatunde LAMIDI, ${ }^{\mathrm{c}}$ Elijah Monday IGANGA \\ *l. PhD Student; Department of Pharmacognosy, Faculty of Pharmacy, University of Ibadan, and ${ }^{b}$ Lecturer \\ Department of Basic and Applied Sciences/Science Laboratory Technology, ${ }^{c}$ Technologist Department of \\ Science Laboratory Technology, Federal Polytechnic Bali, Taraba State, ${ }^{2}$ Department of Veterinary Public \\ Health and Preventive Medicine, Faculty of Veterinary Medicine, Ahmadu Bello University, Zaria, Nigeria.
}

\begin{abstract}
Medicinal plant extracts prepared with ethanol concentrations from the leaves and stem barks of Bridelia ferruginea and Terminalia avicennioides were screened for antibacterial activity against two Grampositive bacteria that cause impetigo contagiosa skin infection in infants and young children. The antibacterial activity of the extracts (100\% absolute ethanol) was evaluated using micro-broth dilution method, for both the bacteria and the antibiotics. Plant extracts showed strong antibacterial action against Gram-positive bacteria, Staphylococcus aureus, methicillin resistance Staphylococcus aureus (MRSA) and Streptococcus pyogenes, while the antibiotics Erythromycin, Chloramphenicol, Ampicloxacin, Tetracycline and Cefroxime did not show strong antibacterial action at different concentrations of ethanol used. Of these extracts, Bridelia ferruginea showed the strongest activity at all concentrations. In the case of Erythromycin and Chloramphenicol, the antibiotics are chemically modified so that it will no longer bind to the ribosome to block protein synthesis, and an enzyme is produced that degrades the antibiotics, thereby inactivating them. The plant extracts were strongly inhibitory towards the MRSA strain unlike the antibiotics. MICs and MBCs varied from $2.5-5 \mu \mathrm{g} / \mathrm{ml}$ to $\leq$ $5-10 \mu \mathrm{g} / \mathrm{ml}$ respectively dilution levels and were in agreement with well assay results. The results showed that the pure extracts of the plants contained terpenes as the active antibacterial constituent, which is largely responsible for the efficacy of the extracts on the bacteria even MRSA strain. However, antibiotics like Cefroxime and Ampicloxacin are highly associated with colonization with "superbugs" compared to other antibiotic classes. A superbug, also called multi-resistant, is a bacterium that carries several resistance genes; the resistance was not strong compared with the plant extracts $(p \leq 0.05)$. The study therefore, showed that ethanol extracts of B. ferruginea and T. avicennioides strongly inhibited the growth as well as kill impetigo contagiosa bacteria than all the antibiotics investigated, and these plants were very safe for ethno-medicinal prescriptions from the toxicity studies conducted.
\end{abstract}

Keywords: Antibiotic resistance, impetigo contagiosa, Staphylococcus aureus, Streptococcus pyogenes, Bridelia ferruginea, Terminalia avicennioides.

\section{Introduction}

Antibiotic resistance is a form of drug resistance whereby some (or, less commonly, all) subpopulations of a microorganism, usually a bacterial species, are able to survive after exposure to one or more antibiotics; pathogens resistant to multiple antibiotics are considered multidrug resistant (MDR) or, more colloquially, superbugs. Microbes, rather than people, develop resistance to antibiotics. ${ }^{[1]}$ Several mechanisms have evolved in bacteria which confer them with antibiotic resistance. These mechanisms can chemically modify the antibiotic, render it inactive through physical removal from the cell, or modify target site so that it is not recognized by the antibiotic. The most common mode is enzymatic inactivation of the antibiotic. An existing cellular enzyme is modified to react with the antibiotic in such a way that it no longer affects the microorganism. An alternative strategy utilized by many bacteria is the alteration of the antibiotic target site. These and other mechanisms are shown in the figure below. 


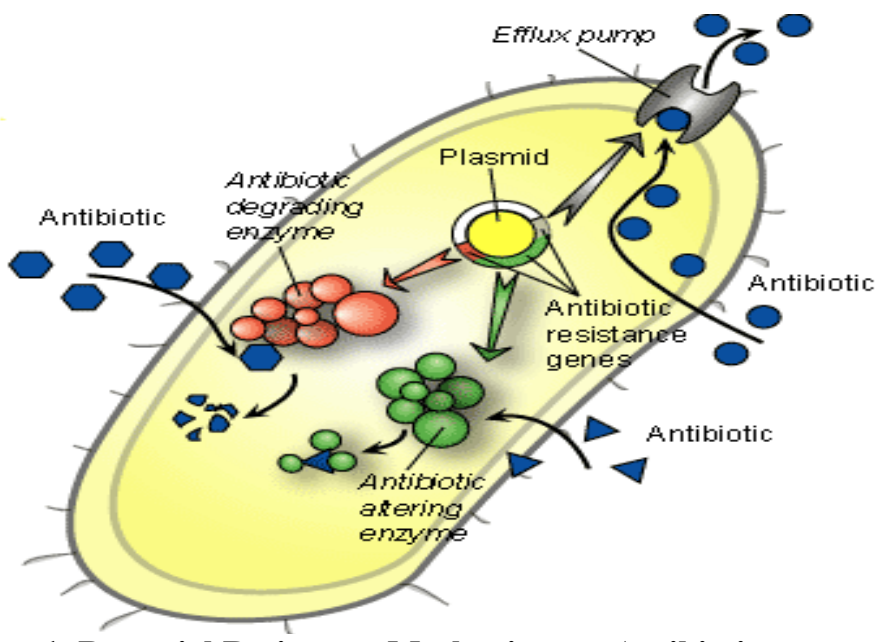

Figure 1: Bacterial Resistance Mechanism on Antibiotics

Antibiotic resistance is a serious and growing phenomenon in contemporary medicine and has emerged as one of the pre-eminent public health concerns of the 21 st century; particularly as it pertains to pathogenic organisms (the term is especially relevant to organisms which cause disease in humans). In the simplest cases, drug-resistant organisms may have acquired resistance to first-line antibiotics, thereby necessitating the use of second-line agents.

Typically, a first-line agent is selected on the basis of several factors including safety, availability and cost; a second-line agent is usually broader in spectrum, has a less favorable risk-benefit profile and is more expensive or, in dire circumstances, is locally unavailable. In the case of some MDR pathogens, resistance to second and even third-line antibiotics is thus sequentially acquired; a case quintessentially illustrated by Staphylococcus aureus in some nosocomial settings. Some pathogens, such as Pseudomonas aeruginosa, also possess a high level of intrinsic resistance.

It may take the form of a spontaneous or induced genetic mutation, or the acquisition of resistance genes from other bacterial species by horizontal gene transfer via conjugation, transduction, or transformation. Many antibiotic resistance genes reside on transmissible plasmids, facilitating their transfer. Exposure to an antibiotic naturally selects for the survival of the organisms with the genes for resistance. In this way, a gene for antibiotic resistance may readily spread through an ecosystem of bacteria. Antibiotic-resistance plasmids frequently contain genes conferring resistance to several different antibiotics. This is not the case for Mycobacterium tuberculosis, the bacteria that causes tuberculosis, since evidence is lacking for whether these bacteria have plasmids. ${ }^{[2]}$ Also. M. tuberculosis lacks the opportunity to interact with other bacteria in order to share plasmids. ${ }^{[2][3]}$

Genes for resistance to antibiotics, like the antibiotics themselves, are ancient. ${ }^{[4]}$ However, the increasing prevalence of antibiotic-resistant bacterial infections seen in clinical practice stems from antibiotic use both within human medicine and veterinary medicine. Any use of antibiotics can increase selective pressure in a population of bacteria to allow the resistant bacteria to thrive and the susceptible bacteria to die off. As resistance towards antibiotics becomes more common, a greater need for alternative treatments arises. However, despite a push for new antibiotic therapies there has been a continued decline in the number of newly approved drugs. ${ }^{[5]}$ Antibiotic resistance therefore poses a significant problem.

The growing prevalence and incidence of infections due to MDR pathogens is epitomized by the increasing number of familiar acronyms used to describe the causative agent and sometimes the infection generally; of these, MRSA is probably the most well-known, but others including VISA (vancomycinintermediate $S$. aureus), VRSA (vancomycin-resistant $S$. aureus), ESBL (Extended spectrum beta-lactamase), VRE (Vancomycin-resistant Enterococcus) and MRAB (Multidrug-resistant A. baumannii) are prominent examples. Nosocomial infections overwhelmingly dominate cases where MDR pathogens are implicated, but multidrug-resistant infections are also becoming increasingly common in the community.

Although there were low levels of preexisting antibiotic-resistant bacteria before the widespread use of antibiotics, ${ }^{[6]}[7]$ evolutionary pressure from their use has played a role in the development of multidrug resistance varieties and the spread of resistance between bacterial species. ${ }^{[8]}$ In medicine, the major problem of the emergence of resistant bacteria is due to misuse and overuse of antibiotics. ${ }^{[9]}$ In some countries, antibiotics are sold over the counter without a prescription, which also leads to the creation of resistant strains. Other practices contributing towards resistance include the addition of antibiotics to livestock feed. ${ }^{[10][11]}$ Household use of antibacterial in soaps and other products, although not clearly contributing to resistance, is also discouraged (as not being effective at infection control). ${ }^{[12]}$ Unsound practices in the pharmaceutical 
manufacturing industry can also contribute towards the likelihood of creating antibiotic-resistant strains. ${ }^{[13]}$ The procedures and clinical practice during the period of drug treatment are frequently flawed - usually no steps are taken to isolate the patient to prevent re-infection or infection by a new pathogen, negating the goal of complete destruction by the end of the course ${ }^{[14]}$

Antibiotic resistance can be a result of horizontal gene transfer, ${ }^{[15]}$ and also of unlinked point mutations in the pathogen genome at a rate of about 1 in $10^{8}$ per chromosomal replication. The antibiotic action against the pathogen can be seen as an environmental pressure. Those bacteria with a mutation that allows them to survive live to reproduce. They then pass this trait to their offspring, which leads to the evolution of a fully resistant colony ${ }^{[15]}$ The four main mechanisms by which microorganisms exhibit resistance to antimicrobials are:

1. Drug inactivation or modification: for example, enzymatic deactivation of penicillin $\mathrm{G}$ in some penicillinresistant bacteria through the production of $\beta$-lactamase

2. Alteration of target site: for example, alteration of PBP - the binding target site of penicillin - in MRSA and other penicillin-resistant bacteria

3. Alteration of metabolic pathway: for example, some sulfonamide-resistant bacteria do not require paraaminobenzoic acid (PABA), an important precursor for the synthesis of folic acid and nucleic acids in bacteria inhibited by sulfonamides, instead, like mammalian cells, they turn to using preformed folic acid.

4. Reduced drug accumulation: by decreasing drug permeability and/or increasing active efflux (pumping out) of the drugs across the cell surface. ${ }^{[12]}$

There are three known mechanisms of fluoroquinolone resistance. Some types of efflux pumps can act to decrease intracellular quinolone concentration. ${ }^{[13]}$ In Gram-negative bacteria, plasmid-mediated resistance genes produce proteins that can bind to DNA gyrase, protecting it from the action of quinolones. Finally, mutations at key sites in DNA gyrase or topoisomerase IV can decrease their binding affinity to quinolones, decreasing the drug's effectiveness. ${ }^{[14]}$ Research has shown the bacterial protein LexA may play a key role in the acquisition of bacterial mutations giving resistance to quinolones and rifampicin. ${ }^{15]}$

Antibiotic resistance can also be introduced artificially into a microorganism through laboratory protocols, sometimes used as a selectable marker to examine the mechanisms of gene transfer or to identify individuals that absorbed a piece of DNA that included the resistance gene and another gene of interest.

Staphylococcus aureus (colloquially known as "Staph aureus" or a "Staph infection") is one of the major resistant pathogens. Found on the mucous membranes and the human skin of around a third of the population, it is extremely adaptable to antibiotic pressure. It was one of the earlier bacteria in which penicillin resistance was found - in 1947, just four years after the drug started being mass-produced. Methicillin was then the antibiotic of choice, but has since been replaced by oxacillin due to significant kidney toxicity. Methicillinresistant Staphylococcus aureus (MRSA) was first detected in Britain in 1961, and is now "quite common" in hospitals. MRSA was responsible for 37\% of fatal cases of sepsis in the UK in 1999, up from 4\% in 1991. Half of all $S$. aureus infections in the US are resistant to penicillin, methicillin, tetracycline and erythromycin.

Streptococcus pyogenes (Group A Streptococcus: GAS) infections can usually be treated with many different antibiotics. Early treatment may reduce the risk of death from invasive group A streptococcal disease. However, even the best medical care does not prevent death in every case. For those with very severe illness, supportive care in an intensive care unit may be needed. For persons with necrotizing fasciitis, surgery often is needed to remove damaged tissue. ${ }^{[16]}$ Strains of $S$. pyogenes resistant to macrolide antibiotics have emerged; however, all strains remain uniformly sensitive to penicillin. ${ }^{[15]}$

The study was designed to determine the resistant mechanisms of the two bacteria that caused Impetigo contagiosa infectious disease in infants and the efficacy of some plants extracts used in folkloric medicine in treating this infectious disease.

\section{Collection and Preparation of Plant materials}

\section{Materials and Methods}

The leaves and stem barks were freshly collected, from a forest at Ogurugu town $49 \mathrm{~km}$ from Nsukka in Enugu State, Nigeria, and identified at the herbarium unit of the Department of Botany, University of Ibadan, where a voucher number was deposited for the plant. Further confirmation was made at International Institute for Tropical Agriculture (IITA), Ibadan. The plants were air dried for six days, and grinded using electrical blender, into fine powders.

\section{Extraction of Plant Materials}

About 200 grams of each of the powdered parts was weighed using electronic scale balance into two separating funnels respectively. $500 \mathrm{mls}$ of absolute ethanol containing $300 \mathrm{mls}$ of water was poured into the samples using cold maceration techniques. The set up were left to stand for 48 hours to enable the constituents dissolve thoroughly in ethanol. The filtrates were collected into a beaker and subsequently transferred into 
evaporating dish in order to concentrate them. The extracts were weighed and percentage yields for each extract was calculated and then stored in desiccators for further use.

\section{Biological Evaluation of Ethanol Extract of Leaves and Stem barks of Plants}

The following were carried out in order to assess the efficacy of the extracts of on Staphylococcus aureus- ATCC 25923, Streptococcus pyogenes- ATCC 19615 and MRSA, bacteria that caused impetigo contagiosa infection in infants. Colonies picked from $24 \mathrm{~h}$ old cultures grown on nutrient agar were used to make suspensions of the test organisms in saline solution to give an optical density of approximately 0.1 at $600 \mathrm{~nm}$. The suspension was then diluted 1: 100 by transferring $0.1 \mathrm{~mL}$ of the bacterial suspension to $9.9 \mathrm{~mL}$ of sterile nutrient broth before being used. All the bacteria were obtained from the Department of Medical Microbiology, University College Hospital, Ibadan, Nigeria.

\section{Antibiotic Susceptibility Testing of Drugs and Extracts (Antibacterial Studies)}

Using well diffusion method [17]. solution concentration of $20 \mathrm{mg} / \mathrm{ml}$ was used as the initial concentration, and blood agar was used as the growth medium. 40 grams of the medium was dissolved in a liters of distilled water contained in a flask capped with cotton wool. The medium was boiled to dissolve on a Bunsen burner. This was then sterilized at $121^{\circ} \mathrm{C}$ for 15 minutes and allowed to cool. $20 \mathrm{mls}$ of the sterilized medium was poured into sterile Petri dishes and allowed to solidify.

The plates (Petri dishes) were then seeded with the test microorganisms by spread plate technique, and left to dry for an hour. With a sterile cork borer $5 \mathrm{~mm}$ in diameter, wells were made at the centre of each plate and seeded with the test organisms. $0.1 \mathrm{ml}$ of the extract was poured into the wells using sterile syringe. The plates were then incubated at $37{ }^{\circ} \mathrm{C} \pm 2{ }^{\circ} \mathrm{C}$ for $24 \mathrm{~h}$. The plates were observed for the zone of clearance around the wells. These zones were measured using transparent ruler (in $\mathrm{mm}$ ) and this represents the inhibition zones. The readings were taken in three different fixed directions in all 3 replicates, and the average values were tabulated. ${ }^{[17]}$ Positive and negative controls using various antibiotics were also seeded in the same way as above to compare the level of significance between the extract and the standard drugs.

\section{Determination of Minimum Inhibitory Concentration (MIC) of the extracts and Drugs}

The MIC was carried out on the microorganisms that showed sensitivity to the extract. This was done using broth dilution methods. ${ }^{[18]}$ The aim was to know the least concentration of the extract that will inhibit or prevent the growth of the bacteria. Nutrient broth was prepared according to the manufacturer's instructions. Ions of the broth was disposed into five test tubes each for the bacteria and sterilized at $121^{\circ} \mathrm{C}$ for 15 minutes. MC-Farland turbidity standard scale number 0.5 was prepared to give a turbid suspension of the microorganisms. Normal saline was also prepared. The microbes were inoculated into the normal saline until the turbidity marched that of the MC-Farland scale by visual comparison. At this point, the microbes have a concentration of $1.5 \times 10^{8} \mathrm{cfa} / \mathrm{ml}$. Dilution of the extracts in the nutrient broth was done for each set of the organisms to obtain concentrations of $20 \mathrm{mg} / \mathrm{ml}, 10 \mathrm{mg} / \mathrm{ml}, 5 \mathrm{mg} / \mathrm{ml}, 2.5 \mathrm{mg} / \mathrm{ml}$ and $1.25 \mathrm{mg} / \mathrm{ml}$. Using a sterile pipette, $0.2 \mathrm{ml}$ of the microbe suspension was transferred into each test tubes, and then incubated at $37^{\circ} \mathrm{C}$ for 24 h. The tubes were observed for turbidity or growth. Test tube with the lowest concentration of the extract showing a clear solution (no turbidity) was regarded as the MIC. ${ }^{[17][18]}$

\section{Determination of Minimum Bactericidal Concentration (MBC) of the Extracts and Drugs}

The MBC was carried out in order to determine whether the microbes were killed or only their growths were inhibited. Blood agar was prepared according to the manufacturer's instructions and sterilized at $121^{\circ} \mathrm{C}$ for 15 minutes. It was poured into sterile Petri dishes and left to solidify. The plates were labeled accordingly to correspond to the MIC test tubes. The contents of the MIC in the proceeding test tubes in the serial dilution were sub cultured into the plates by dipping a sterile wire loop and streaking the surface of the agar, in the plates. The plates were thus incubated at $37^{\circ} \mathrm{C}$ for $24 \mathrm{~h}$ after which they were checked for growth. The plate with the lowest concentration of extract without growth was taken as the MBC. ${ }^{[17][18] 19] .}$

\section{In vivo Experiment (Inoculation of Albino Mice with Bacterial Stocks)}

Fourteen (14) albino mice weighing between 25 and $32 \mathrm{~kg}$ were divided into two groups of seven animals each. Group one was inoculated with a stock containing Staphylococcus aureus except one animal which served as the control while group two was inoculated with Streptococcus pyogenes, following intraperitoneal route (i.p). After the development of infection (impetigo), the two groups were each administered $5 \mathrm{ml} / \mathrm{kg}$ of extracts, tetracycline, erythromycin, cefroxime, and ampicloxacin antibiotics (i.p), with each animal receiving one treatment. Recovering from the infection after seven working days was taken to indicate the efficacy of the treatment drugs on the disease. 
Resistance of the bacteria to the antibiotics, and efficacy of the extracts were determined using molecular techniques as well as biochemical pharmacological procedures. [20][21][23].

\section{Determination of Rate of Kill of Bacterial by Purified Extracts}

Determination of Rate of Kill Assays for the rate of killing bacteria by the pure ethanol extracts were carried out using a modified plating technique of G. M. Eliopoulos and C. T. Eliopoulos ${ }^{[21]}$ and Eliopoulos and Moellering ${ }^{[22]}$. The extract was incorporated into $10 \mathrm{~mL}$ Mueller Hinton broth in McCartney bottles at 1/2 MIC, $1 \times$ MIC, and $2 \times$ MIC. Two controls, one Mueller Hinton broth without extract inoculated with test organisms and Mueller Hinton broth incorporated with the extract at the test concentrations without the test organisms, were included. Inoculums density, approximately $105 \mathrm{cfu} / \mathrm{mL}$ further verified by total viable count, was used to inoculate $10 \mathrm{~mL}$ volumes of both in the McCartney bottles and control bottles. The bottles were incubated at 37 ${ }^{\circ} \mathrm{C}$ on an orbital shaker at $120 \mathrm{rpm}$. A $100 \mu \mathrm{L}$ aliquot was removed from the culture medium at 0,4 , and $8 \mathrm{~h}$ for the determination of $\mathrm{cfu} / \mathrm{mL}$ by the plate count technique ${ }^{[21]}$ by plating out $25 \mu \mathrm{L}$ of each of the dilutions. The problem of extract carryover was addressed by dilution as described previously by Pankuch et al., ${ }^{\text {[24] }}$. After incubating at $37^{\circ} \mathrm{C}$ for $24 \mathrm{~h}$, emergent bacterial colonies were counted, cfu/mL calculated, and compared with the count of the culture control without the extracts.

\section{Toxicity Study of leaves and Stem bark Ethanol Extracts of Plants}

0.5 gram of the extracts were weighed and prepared into appropriate milliliters in order to determined the lethal dose $\left(\mathrm{LD}_{50}\right)$ (acute toxicity) of the extracts in Swiss white male albino mice numbering thirty-nine(26) i.e. thirteen(13) for each extract. The animals were weighed using an electronic scale balance. The experiment was divided into two phases. In the phase one, nine (9) animals of three (3) animals per group were used and doses of $10 \mathrm{mg} / \mathrm{kg}, 100 \mathrm{mg} / \mathrm{kg}$ and $1000 \mathrm{mg} / \mathrm{kg} \mathrm{b}$.w ethanol extracts administration i.p were given to the animals. The animals were fed with ordinary water on the first day and afterwards with maize feeds, and then monitored for any deaths and changes in behaviour for one week during the working days.

In the second phase, the remaining four (4) animals were divided into 3 groups of one animal per group and administered the doses of $1600 \mathrm{mg} / \mathrm{kg}, 2900 \mathrm{mg} / \mathrm{kg}$ and $5000 \mathrm{mg} / \mathrm{kg}$ b.w ethanol extract (i.p) and observed for changes and death for $24 \mathrm{~h}$. The $\mathrm{LD}_{50}$ (Acute toxicity) was calculated as the geometric mean of the dosage that resulted in $100 \%$ mortality and that dosage which cause no mortality at all. Recovery and body weight gain after each investigation was taken as a sign of surviving the acute intoxication. The experiment was terminated after two weeks 20$]$.

\section{Statistical Analysis}

All statistical analysis was based on the student's T-test by Snedecor and Cochran ${ }^{[26]}$.

\section{Results}

The antibacterial activity of the stem bark ethanol extract of $B$. ferruginea and $T$. avicennioides was evaluated by both agar diffusion and dilution assays against bacteria associated with impetigo contagiosa skin infection. The degree of the antibacterial activity was assayed by serial twofold dilution method to determine the minimum inhibitory concentration (MIC) of the extract ${ }^{[22]}$. The two assay methods showed that the bacteria exhibited varied susceptibility to the extract at the different concentrations used ${ }^{[\text {Table } 2]}$. The zones of inhibition obtained from $2.5 \mu \mathrm{L} / \mathrm{mL}$ of erythromycin ranged between 10 and $25 \mathrm{~mm}$. At the highest concentration of the extracts $(200 \mu \mathrm{g} / \mathrm{mL})$, Staphylococcus aureus (ATCC 25923) had the widest zone of inhibition (29 mm), while MRSA and Streptococcus pyogenes (ATCC 19615) had the least zone of inhibition (21 mm). ${ }^{[T a b l e ~ 2]}$.

Table 1: Antibiotics Resistance Mechanisms

\begin{tabular}{ll}
\hline Antibiotic & Method of resistance \\
\hline Chloramphenicol & reduced uptake into cell \\
Tetracycline & active efflux from the cell \\
$\beta$-lactams, Erythromycin, & eliminates or reduces binding of antibiotic to cell target \\
Ampicloxacin & enzymatic cleavage or modification to inactivate antibiotic \\
$\beta$-lactams, Aminoglycosides, & molecule \\
Chloramphenicol & metabolic bypass of inhibited reaction \\
Cefroxime & overproduction of antibiotic target (titration) \\
Sulfonamides, Trimethoprim &
\end{tabular}

Three mechanisms of antibiotic resistance in bacteria ${ }^{[\text {Fig. } 1-3] .}$ Most, but not all, resistance mechanisms are encoded by plasmids, which are potentially transmissible to other bacteria. Clockwise: 12 o'clock: Efflux pumps 
are high-affinity reverse transport systems located in the membrane that transport the antibiotic out of the cell. This is the mechanism of resistance to tetracycline. 4 o'clock: A specific enzyme modifies the antibiotic in a way that it loses its activity. In the case of streptomycin, the antibiotic is chemically modified so that it will no longer bind to the ribosome to block protein synthesis. 9 o'clock: An enzyme is produced that degrades the antibiotic, thereby inactivating it. For example, the penicillinases are a group of beta-lactamase enzymes that cleave the beta lactam ring of the penicillin molecule ${ }^{[\text {Fig.2] }}$

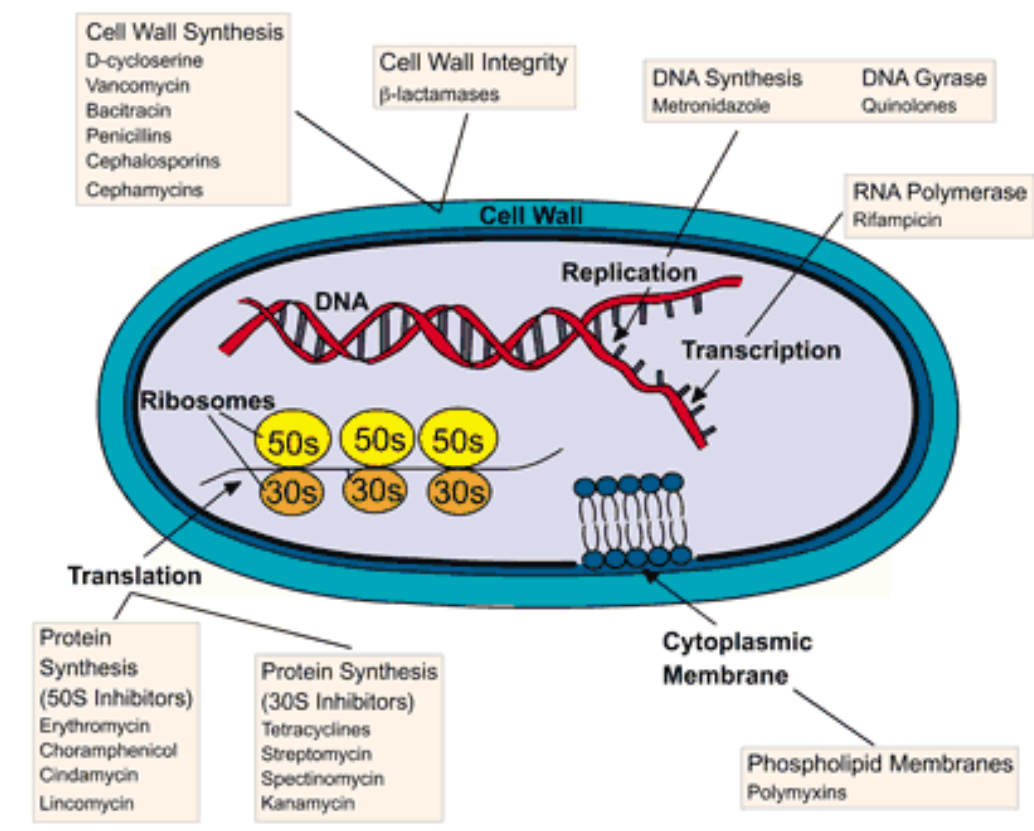

Figure 2: Staphylococcus aureus resistance mechanisms by DNA replication in mice using electron microscope

The combined effects of fast growth rates to large densities of cells, genetic processes of mutation and selection, and the ability to exchange genes, account for the extraordinary rates of adaptation and evolution that can be observed in the bacteria. For these reasons bacterial adaptation (resistance) to the antibiotic environment seems to take place very rapidly in all the antibiotics investigated. Bacteria evolve fast! [Table 1][Fig.3]. A lot of mechanisms were developed by the bacteria as a result of extract administration, thus making the extracts to resist any form of resistance by the bacteria. [Fig. 4]

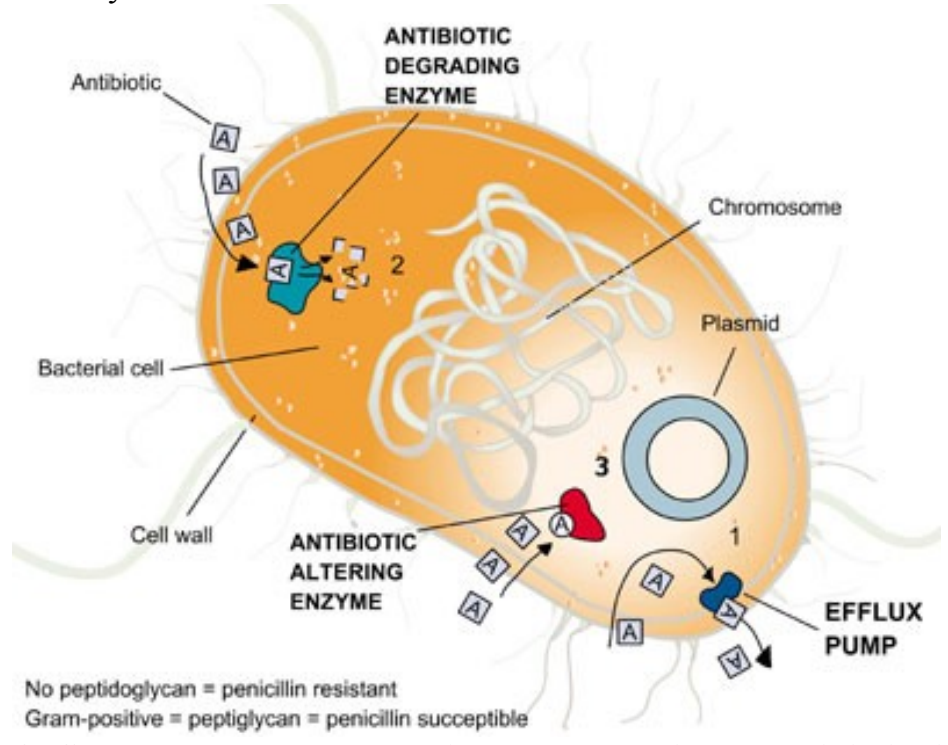

Figure 3: Streptococcus pyogenes resistance mechanism to antibiotics in mice 


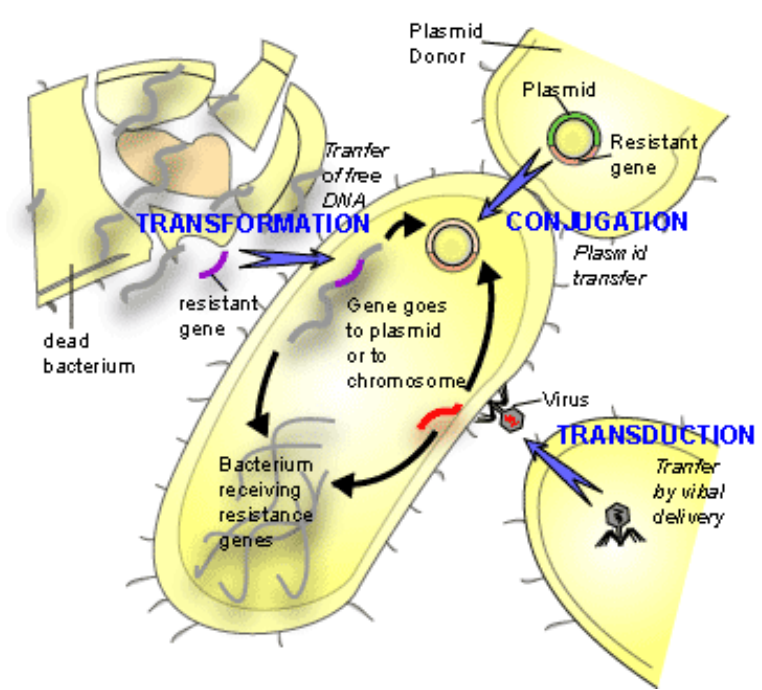

Figure 4: Extracts and Bacteria interaction in vivo

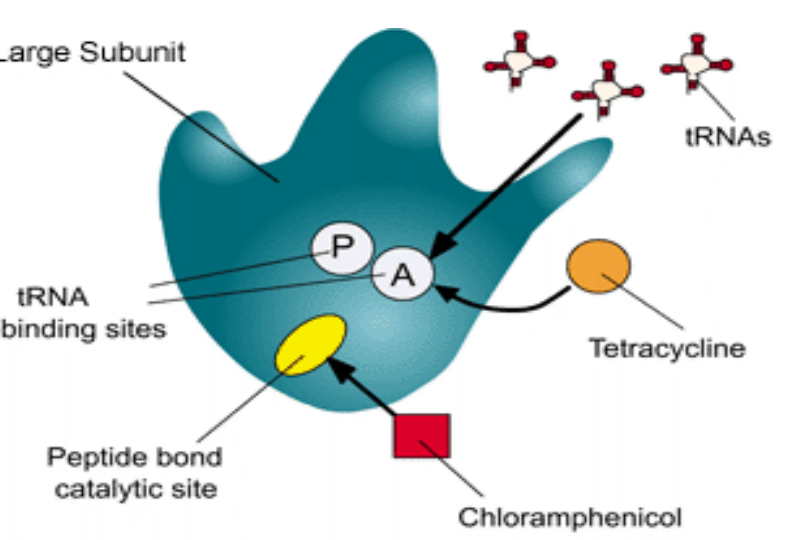

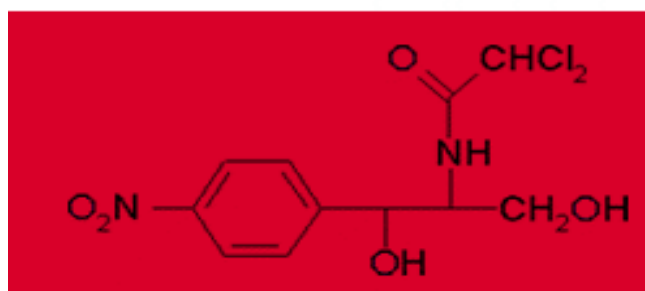

Chloramphenicol binds to the 50 s subunit of the ribosome and blocks the peptide site of the ribosome, inhibiting peptide-bond formation.

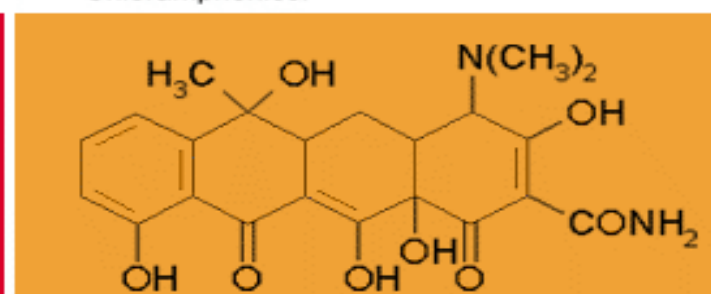

Tetracycline prevents binding of tRNAs to the acceptor site of the ribosome.

Figure 5: Antibiotics binding sites in mice in vivo
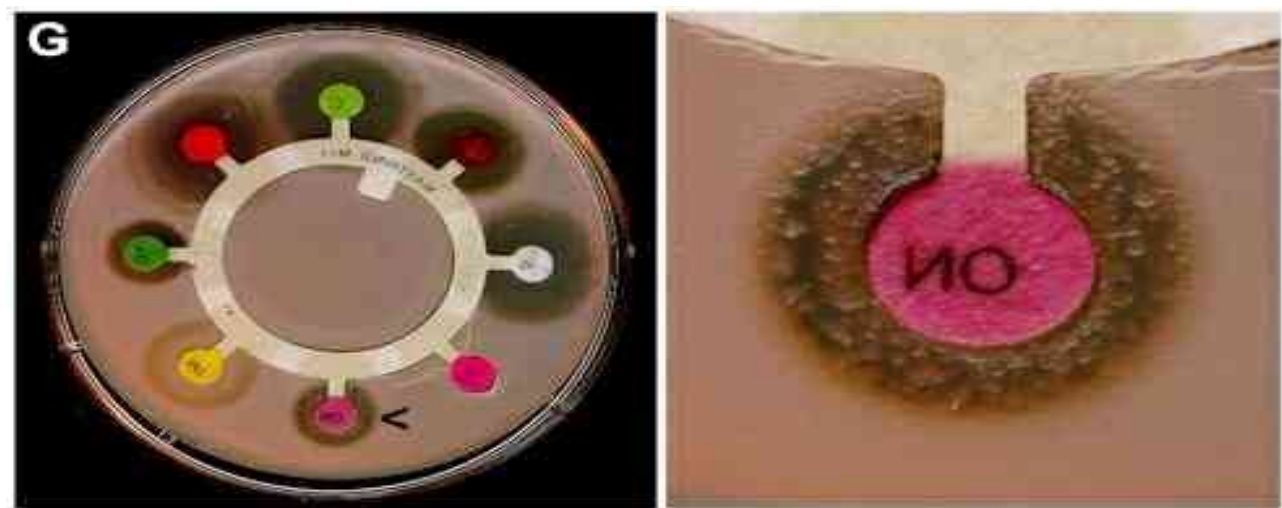

Figure 6: Antibiotic disc and bacteria behaviour for erythromycin $5 \mathrm{ml} / \mathrm{kg}$ 
Tests for sensitivity and resistance to antibiotics.

(Left) The size of the zones of inhibition of microbial growth surrounding the antibiotic disks on the plate is an indication of microbial susceptibility to the antibiotic. (Right) By the use of these discs it is also possible to detect the occurrence of individual mutants within the culture that have developed antibiotic resistance. The image ${ }^{[\mathrm{Fig} .6]}$ shows a close-up of the erythromycin disc (marked by an arrow on the whole plate) near which individual mutant cells in the bacterial population that were resistant to the antibiotic and have given rise to small colonies within the zone of inhibition.

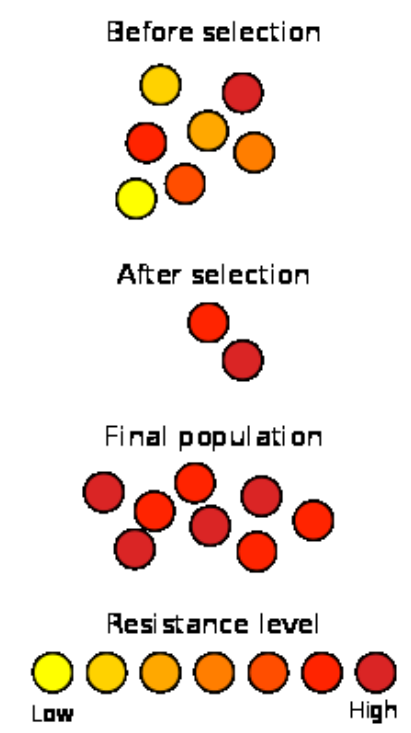

Figure 7: Schematic representation of how antibiotic resistance evolves via natural selection.

The top section ${ }^{[\mathrm{Fig} .7]}$ represents a population of bacteria before exposure to an antibiotic. The middle section shows the population directly after exposure, the phase in which selection took place. The last section shows the distribution of resistance in a new generation of bacteria. The legend indicates the resistance levels of individuals.

Table 2: Zones of inhibition of leaf extract Against the Microbes

\begin{tabular}{lccc}
\hline Test Organism & \multicolumn{3}{c}{ Mean zone of inhibition \pm SE } \\
\cline { 2 - 4 } & $\underline{\text { Extract B }}$ & Chloral. & Erythromycin \\
\cline { 2 - 4 } Staphylococcus aureus & $39 \pm 0.42$ & $5 \pm 0.11$ & $8 \pm 0.17$ \\
Streptococcus pyogenes & $37 \pm 0.21$ & $8 \pm 0.21$ & $7 \pm 0.60$ \\
MRSA & $38 \pm 0.42$ & $4 \pm 0.64$ & $6 \pm 0.50$ \\
Shigella dysenteriea & $36 \pm 0.41$ & 0 & $23 \pm 037$ \\
\hline
\end{tabular}

NB: Zero (0) denotes organism that showed resistant to the drugs, Chloral is chloramphenicol tablet, $\mathrm{P} \leq 0.05$ (ttest), Extract $\mathrm{B}$ is Bridelia ferruginea extract, the higher the diameter zone of inhibition, the more efficacy the drug, $\mathrm{n}=3$.

In ${ }^{[\text {table } 2]}$ above, the bacteria exhibited higher diameter zone of inhibition with the extracts than the antibiotics, and they are more likely to be potent on the microbes.

Table 3: Minimum Inhibitory Concentration (MIC) and Minimum Bactericidal Concentration (MBC) of Extracts against the Microbes

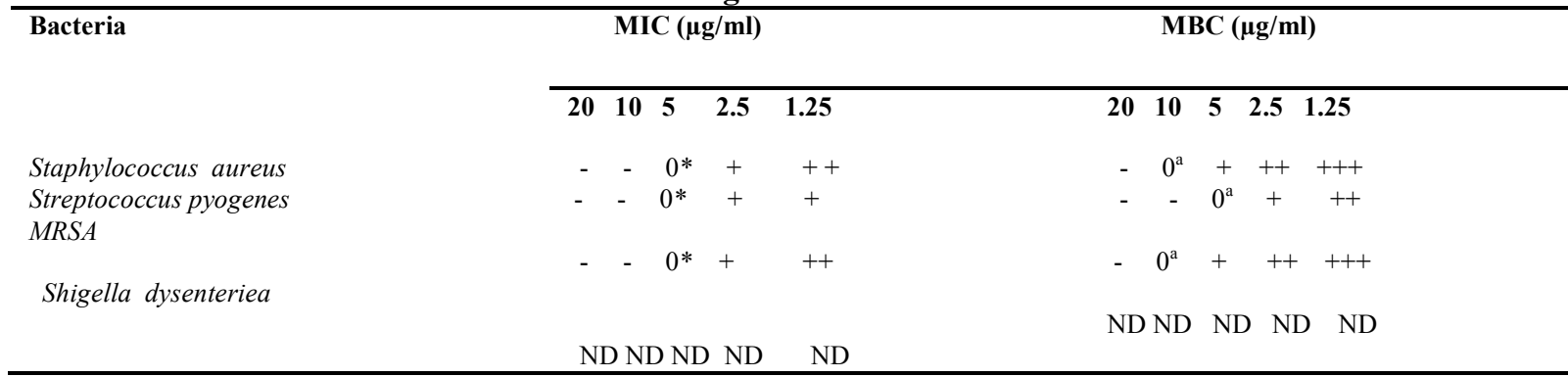


- (clear), + (light growth), ++ (dense growth), $0^{*}(\mathrm{MIC}), 0^{\mathrm{a}}$ (MBC), +++ (highly growth), ND (not determined).

\section{Discussion}

Medicinal plants have been unique sources of medicines and constituted the most common human use of biodiversity ${ }^{[24]}$. The traditional use of medicinal plants, being before the advent of antibiotics and other modern drugs ${ }^{[25]}$ and their use worldwide for thousands of years with more than $80 \%$ of the world's population depending on traditional medicines for various diseases $[23]$, implicated the anticipations of scientists that phytochemicals with adequate antibacterial efficacy will be useful for the treatment of bacterial infections ${ }^{[21]}$. Consequently, many ethno-pharmacological studies are being conducted to determine their safety, efficiency, and discovery of new active principles in the recent times while many medicinal plants and plants' products with antibiotic actions have become a significant source of many potent and powerful drugs as well as the main source of new leads for antimicrobial remedies and pharmaceutical development. Inappropriate prescribing of antibiotics has been attributed to a number of causes, including people who insist on antibiotics, physicians who simply prescribe them as they feel they do not have time to explain why they are not necessary, and physicians who do not know when to prescribe antibiotics or else are overly cautious for medical legal reasons. ${ }^{\text {[22][Fig.1][Table1] }}$

In this study, the pure ethanol extract of $B$. ferruginea demonstrated significant inhibitory and bactericidal effects against all the test bacteria ${ }^{[T a b l e ~ 2]}$. The differences in the values of MICs and MBCs suggested a selective antibacterial activity of the extract, while the varied susceptibility of the different bacteria isolates was extract concentration dependent. Although Ríos and Reco ${ }^{[27]}$ suggested that MIC greater than $100 \mu \mathrm{g} / \mathrm{mL}$ of crude extracts or $1000 \mu \mathrm{g} / \mathrm{mL}$ for isolated compounds should be avoided and proposed that activity would be very interesting in MICs of $100 \mu \mathrm{g} / \mathrm{mL}$ and $10 \mu \mathrm{g} / \mathrm{mL}$ for crude extracts and isolated compounds respectively, Fabry et al. ${ }^{\text {[28] }}$ defined active crude extracts as those having MIC values $<8000 \mu \mathrm{g} / \mathrm{Ml}$. Hence, since lower MIC and MBC values indicate higher efficacy ${ }^{[24]}$, and phytochemicals are routinely classified as antimicrobials when susceptibility tests had MICs in the range of $100-1000 \mu \mathrm{g} / \mathrm{mL}$ [26] the MICs and MBCs of less than $1000 \mu \mathrm{g} / \mathrm{mL}$, in this study, were considered to be of good activity. The MIC index values, being less than or equal 5 , indicated the bactericidal attribute of the pure ethanol extract and suggested that bactericidal effects of the pure extracts could be expected on most of the tested organisms in a disease state. Where MIC equals MBC, the bactericidal potential with a broad spectrum and great therapeutic potential of the plant is indicated as seen in the extracts ${ }^{[\text {Table } 3]}$.

Furthermore, the resultant effect of incubating the bacteria at $2 \times$ MICs was a significantly rapid reduction in the average of the viable cells counted. This reduction is greater than the rate of kill observed in the bacteria treated with the $1 \times$ MICs. The significant reduction in the cell counts between 4 and $8 \mathrm{~h}$ of incubation period acknowledged the fact that the extract was highly bactericidal seeing that the bacterial colonies were almost totally wiped out after incubating for $8 \mathrm{~h}$. On the contrary, there was a net growth of all the test isolates treated with the $1 / 2 \times$ MICs of the extracts. While the growth inhibition and efficacy of the ethanol stem bark extract were dose and time dependent to present effective time-kill profiles for the tested bacteria, the results of the antibacterial assays determined by the agar diffusion and dilution methods as well as the macro-broth dilution assay are complementary. These results were further substantiated by the observed rate of kill and the effectiveness of the extract's bactericidal activity as indicated by the time-kill assay. While the degree of antibacterial activity may be accounted for by the terpenoids synthesized by plants in response to microbial infection, and the active components in the extracts may be acting synergistically to produce good antibacterial effects ${ }^{[28]}$, the disparity between the activities of the extract and the standard antimicrobial drug may be due to the mixtures of bioactive compounds present in the extract compared to the pure compound contained in the standard antibiotics ${ }^{[29]}$.

Although in vitro tests do not necessarily confirm that plant extracts are either effective medicines or a suitable candidate for drug development, it provides a basic understanding of a plant efficacy and leads to the search for new active substances as well as validating its use in traditional medicine. In ethno-therapy, the recorded antibacterial activity of the crude ethanol extract of B. ferruginea and T. avicennioides are of potential importance in the health care delivery system. It showed that the plant could be used as an alternative to orthodox antibiotics in the treatment of infectious diseases caused by these microorganisms. Since investigating the pharmacological activity of plant extract could afford the designing of less expensive therapeutic agents to be used in economically less privileged regions ${ }^{[29]}$, the pure extract could offer a considerable potential opportunity for the development of new agents effective against infections currently difficult to treat with standard antibiotics, because the resistance shown by the bacteria ${ }^{[30]}$. With these expectations, many pharmaceutical companies have renewed their interest in investigating higher plants as sources for new lead structures and the development of standardized antimicrobial agents of proven efficacy, safety, and quality. Consequently, understanding the chemical nature and isolating the active principle(s) in these plants will provide an opportunity to synthesize new and effective antibacterial drugs. The identification of plants able to inhibit efflux pumps is important as they provide a potential for lead optimization and future use with an 
existing antibacterial rendered ineffective due to MDR pumps in both Gram-positive and Gram-negative bacteria $\cdot[$ [Fig.5-7]

Some enhancing activity by the extracts was also detected with the wild-type strains, but not for those that lacked components of the AcrAB-TolC efflux pump when tested with erythromycin, chloramphenicol, tetracycline or cefroxime ${ }^{[\mathrm{Fig} .1]}$. However, significant reductions were recorded with each plant extract in combination with any of these drugs tested against strains over expressing AcrAB-TolC. The reduction in MIC of these drugs ranged from 4-fold up to 32-fold. An enhancing activity was demonstrated by the extracting solvent alone. These extracts are of interest as they represent an efflux transporter that is difficult to inhibit due to the greater resistance afforded to the Gram-negative cells due to the presence of the outer membrane.

\section{Conclusion}

The ethanol extracts of Bridelia ferruginea and Terminalia avicennioides caused an increase in ethidium bromide uptake in $S$. aureus ATCC 25923, containing the pWBG32 plasmid encoding for an ethidium bromide efflux mechanism. These extracts exhibited synergic interactions with chloramphenicol, tetracycline, ampicloxacin, cefroxime and erythromycin against the MRSA tested. The effect of ethanol alone to assess possible interference in the potentiating assay has not been stated by others authors before.

This review has highlighted a number of bacterial EPIs derived from natural sources, primarily from plants. The activities of some of these compounds are appreciable and warrant further study as possible candidates for lead optimization. It is our belief that plants should be further exploited for their potential to produce compounds capable of blocking the mechanism of efflux. There is an ecological rationale for the production of natural products that modify bacterial resistance. It has been speculated that plants have evolved compounds which evade MDR mechanisms and that plant antimicrobials might be developed into broadspectrum antibiotics in combination with inhibitors of MDR. Some of the compounds described exerted both an antibacterial and potentiating activity.

An important issue when identifying a potential efficacy of plants is to ensure that the activity being displayed is due to the interference of efflux rather than any other antibacterial activity, and our findings showed that pure ethanol extracts of leaves and stem barks of Bridelia ferruginea and Terminalia avicennioides displayed strong potency on impetigo contagiosa bacteria studied, by modifying the DNA structure of the bacteria.

\section{Acknowledgement}

The authors are grateful to McLeish Center for Scientific Research, Lagos, Nigeria and the Center for Culture Collection, London, UK; for their helps in this research work.

\section{References}

[1]. Ijeh, I.I and Ukweni, A .I (2007). Acute Effect of Administration of Ethanol Extracts of Ficus exasperata Vahl on kidney function in albino rats. In: Journal of Medicinal Plant Research Vol. 1(2): 027 -029, Sept, 2007.

[2]. ILSI (2005). Flavonoids and Heart Health. In: Proceedings of the ILSI North America Flavonoids Workshop, June, 2005, Washington (USA):34-46.

[3]. Islam, A., Sayeed, A., Bhuiyan, M.S, and Mojaddik, M.A (2001).Antimicrobial Activity and Cytotoxicity of zanthoxylum budrunga. Fitoterapia 72: 428-430.

[4]. Jayeola, A.A (1998). Surface Sculpturing of Alstonia boonei De wild. and A. congensis Engl. (Apocyanaceae) and its importance on their taxonomy. Feddes Report. 109 (5-6): 429-433.

[5]. Katzung, BG and Parmely, W.W (1989). Cardiac Glycosides and other drugs use in congestive heart failure. In: Basic and Clinical Pharmacology.Katzung, B.G (ed) $4^{\text {th }}$ edition, Prentice Hill international Inc. Pp. 165-182.

[6]. Khatune, N.A ;Modsnaddik, M.A and Haque, M.E (2001). Antibacterial activity and cytotoxicity of Nyctanthes arbar tristis flowers. Fitoterapia 72:412-414.

[7]. Kokate, C.K (1986). Practical Pharmacognosy $4^{\text {th }}$ ed. Vallabh Prakashan, Delhi - 110088, 2001, pp $115-121$.

[8]. Konkwara, J.O (1976). Medicinal Plants of East Africa. Literature Bureau, Nairobi. Pp3-8.

[9]. Kumar, R. and Singh, M. (1984). Tannins: Their Adverse Role in Ruminant Nutrition J. Agric food Chem. $32: 447$ - 453.

[10]. Lewington, A., Parker, E. and Corner, E.J (1999).Ancient Trees: Trees that live for 100 years, London, Collins and Brown Ltd, 192 p.

[11]. Lorke, D. (1983). A New Approach to Practical Acute Toxicity testing. Arch Toxicol 1988; $53: 275$-89.

[12]. Mbata, T.I and Saika. A (2008). Antibacterial activity and phytochemical screening of crude ethanolic extract of leaves of Ocimum gratissimum L. on Listeria monocytogenes. In: The internet journal of microbiology. 2008,

a. $\quad$ vol. 4(2).

[13]. Meenaa, V. Gandhiraja, N, Sriram, S. Srilakasmi, J.K, Sasikumar, C. and Rajeswari, R. (2009). Phytochemical screening and antimicrobial activity of the plant extracts of Mimosa pudica L. against selected microbes. In: Ethnobotanical leaflet 13: 618-24.

[14]. Nina, R, Weiblen, G.D and Cook, J.M. (2005). "60 Million years of Co-divergence in the fig-wasp symbiosis". Proceeding of the Royal Society of London Series B, Biological sciences 272 (1581): 2593-2599.

[15]. Obi, V.I and Onuoha, C. (2000). Extraction and Characterization of Natural Products. In: Biological and Agricultural Techniques,55-68.

[16]. Obute, G.C and Osuji, L.C (2002). Environmental Awareness and Dividends: A scientific discourse. African journal of interdisciplinary studies 3(1): $90-94$.

[17]. Odebiyi, O.O and Sofowora, E.A (1978). Phytochemical Screening of Nigerian Medicinal Plants - parts II, lloydia, 41, 234. 
[18]. Ojalla, T. Remes, S. and Hams, P. (1999). Antimicrobial Activity of Some Coumarin containing herbal plants growing in Finland. $J$. Ethnopharmacology 68 (1-3): 267-274.

[19]. Okujagu, T.F (2005). Welcome address at the zonal training medicine Practitioners, Port-Harcourt, Nigeria Natural Medicine Development Agency, Federal Ministry of Science And Technology.

[20]. Onyeyili, A.D, Agbaje, E.O and Asalam, M. (1998). Toxicological study of the extracts of anti-malarial medicinal plant Enantia chorantha. University of Lagos.

[21]. Eliopoulos G.M, Eliopoulos, C.T (2001). Acute Toxicity and Chronic Toxicity Studies:

[22]. Estimation of $\mathrm{LD}_{50}$ and $\mathrm{ED}_{50}$ of some South African figs. In: Plant products research

[23]. Journal, Vol. II (19): 50-58.

[24]. 22. Rang, H.P., Dale, M. and Ritter, J. (2001). Pharmacology $4^{\text {th }}$ edition (USA Ed.) New York, Church hill Livingstone.

[25]. Ressel, A.D and Furr, J.R (1977). Antibacterial Activity of New Chloroxenol Preparation containing ethylene diamine tetracetic acid. J. Appl. Bacterial. 43:253-260.

[26]. Pankuch, F.B, Hilton, V, Loius, G.A. (1999). Bacteria in Biology, Biotechnology and Medicine, $4^{\text {th }}$ edition. John Wiley and sons Ltd, New York, Pp. $324-337($ s).

[27]. Smith, A.G, Dembeck, B.J and Carski, T.R (1968). BBL Manual of Products and Laboratory Procedures $5^{\text {th }}$ edition (eds.), 35p.

[28]. Snedecor, G.W and Cochran, W.G (1967). A statistical Method. Lowe State University Press, Ames, Lowe, USA(s)

[29]. Sodipo, O.A, Akim, F.E, Ahmed, M.M (1991). Saponin is the active antifungal principle in Garcinia kola, Heckle seed, Biosci. Res. Commum 3: 171.

[30]. Tilton, R.C and Howard, B.J (1987). Anti -microbial Susceptibility Testing. In:Carson, D, and Birchor, S (eds.) Clinical and Pathogenic Microbiology. Mosby Co. St. Luis, pp $121-115(\mathrm{~s})$

[31]. USFDA, (2009).Proposed Implementation of International Conference on Harmonization (ICH) Safety Working Group Consensus Regarding new Drug Applications, Pp.45-66.

[32]. Veermuthu, D., Muniappan, A, Savarimuthu, I. (2008).Antimicrobial Activity of Some Ethnomedicinal Plants Used By Paliyar Tribe from Tamilnadu,India.BMC Complemetary \& Alternate Medicine 6 (35). 